\title{
Innovation in SMEs and Financing Mix
}

\author{
Joanna Błach *(D), Monika Wieczorek-Kosmala ${ }^{(\mathbb{D})}$ and Joanna Trzęsiok $(\mathbb{D}$ \\ College of Finance, University of Economics in Katowice, ul. 1 Maja 50, 40-287 Katowice, Poland; \\ m.wieczorek-kosmala@ue.katowice.pl (M.W.-K.); joanna.trzesiok@ue.katowice.pl (J.T.) \\ * Correspondence: jblach@ue.katowice.pl
}

Received: 12 August 2020; Accepted: 8 September 2020; Published: 10 September 2020

check for updates

\begin{abstract}
This study addresses the types of innovation activity of SMEs (Small and medium-sized enterprises) in the European Union and its association with financing decisions. The main objective is to capture the cross-country differences in the types of innovation in SMEs and then investigate the relationship between the types of innovations and relevance of a given type of funding. In the empirical examinations, we use the non-parametric methods, due to the nature of the data. We have found out that there are differences in the types of innovation activity of SMEs in the cross-country dimension. We have also confirmed the contingencies between the types of innovations undertaken by SMEs in each cluster of the European countries, which suggests that various types of innovations co-exist. However, we have not found any unified pattern of correlations between the relevance of a given source of financing and a given type of innovation. Our study contributes to the ongoing debate on the different intensity of innovation activity of SMEs, as linked to the problem of the SMEs financing gap as one of the fundamental drivers of innovation.
\end{abstract}

Keywords: SMEs financing; financing gap; innovative activity; innovation; capital structure decisions

\section{Introduction}

Small and medium-sized enterprises (SMEs) are regarded as the dominant vector of economic progress, as their successful activity determines regional and country development, creates new jobs, supports market competition, and enhances innovation (Beck et al. 2005; Kersten et al. 2017; Savlovschi and Robu 2011). High flexibility and entrepreneurial spirit are the key attributes of SMEs (Thurik and Wennekers 2004). Thus, SMEs remain the crucial players in the knowledge-based economy, as they can respond flexibly to new opportunities, diversify their activities, and create new products, processes, and organization forms. Innovative activity of SMEs results in multiple applications, and their gains may be shared through knowledge and information spill-overs with other firms (Organisation for Economic Co-operation and Development, OECD 2013). In this respect, SMEs are regarded as the main driving force of innovation.

However, SMEs are quite heterogeneous (e.g., sector, size, age, profitability) and they operate in different business environments (e.g., macroeconomic factors, institutional system, financial market, banking sector). Thus, the level of their innovative activity may vary across countries, which was confirmed in prior research (e.g., Pełka 2018).

It is empirically confirmed that innovation activity of SMEs is limited by the accessibility of sufficient funds (Goujard and Guérin 2018; Hall 2010). In this respect, this study contributes to the ongoing debate on SMEs financing decisions and the existence of financing (capital) gap (Angilella and Mazzù 2015; De Moor et al. 2016; Hottenrott and Peters 2012). However, the existing body of the literature in this field remains focused on the public support for innovative SMEs, as it has been confirmed that firms may face difficulties in finding external market-based finance for intangible (knowledge-based) assets (Lee et al. 2015; Vasilescu 2014). Numerous studies have also examined the 
relevance of venture capital funding and recently—crowdfunding, in the context of innovative SMEs (Anwar 2018; Baldock and Mason 2015; Kijkasiwat and Phuensane 2020; Schenk 2015). The relevance of debt finance and internal funding (determined by the efficient performance) in enhancing innovation in SMEs remains relatively less explored (Kerr and Nanda 2015; Sau 2007).

Facing this research gap, the main objective of this study is to capture the cross-country differences in the innovation activity of European SMEs and then to investigate the relationship between the types of innovation and relevance of a given type of funding. In this respect, there are two main contributions of our study to the existing body of the literature. First, it contributes to the debate on the cross-country differences in SMEs innovation activity. Second, it contributes to the debate on the SMEs' financing gap as one of the fundamental drivers of their innovative activity.

In the empirical examinations, this study relies on the data provided in the Survey of Access to Finance of Enterprises (SAFE) reports (SAFE 2018). SAFE regularly analyzes numerous aspects of the European SMEs performance and thus enables to study the differences and similarities in the firms' behaviors. In this study, we use the data that reflect the types of SMEs innovation (within product, market, process, and sales) and the relevance of various types of financing to detect the similarities and the differences of SMEs performing in different European countries.

The remainder of the paper is structured as follows. In the second section, we briefly review the related literature to highlight the conceptual framework of the study. In the third section, we explain the research design and methodology. The fourth section presents and discusses the results of empirical investigations. In the final section, we conclude.

\section{Literature Review}

In the conceptual dimension, this study is merging two streams of literature: innovation activity of SMEs and financial management. The first part derives from the premises of the innovation theory formulated originally by J. Schumpeter, developed further by numerous researchers in the field. Within the second part, the study refers primarily to the discussion on SMEs financing decisions and the persistence of the phenomenon known as financing (capital) gap.

\subsection{SMEs and Innovations}

In the 1930s, J. Schumpeter defined innovation as the introduction of new or qualitative change in existing products, processes, markets, sources of supply of inputs, and organizations. Innovation encompasses a creative activity, the element of novelty, as well as the disruptive change and is often described as a complex, multi-actor process, determined by numerous factors (Assink 2006; Boer and During 2001).

In economic literature, various classifications of innovation have been applied. However, the most common approach is based on the OECD methodology and distinguishes between product, process, organization, and market innovation (Oslo 2018).

Product innovation is defined as any goods, service, or idea that is perceived by its users as new. Process innovation includes the adaptation of existing production lines and the installation of entirely new infrastructure and the implementation of new technologies. Any changes in marketing, purchases and sales, administration, management, and staff policy are classified as organization innovation. In addition, market innovation encompasses the exploitation of new territorial markets or the penetration of new market segments in the existing markets. This approach is widely applied e.g., in the studies by: (Baregheh et al. 2012; Boer and During 2001; Tavassoli and Karlsson 2015 or Varis and Littunen 2010).

J. Schumpeter discussed the importance of SMEs in the context of the innovation process in one of his pioneer works (Schumpeter Mark 1 presented in Schumpeter 1934). He insisted that new, small, entrepreneurial firms are likely to be the source of most innovations, searching creatively for the new market opportunities. However, later, he focused on capital market imperfections and claimed that large, mature firms have better access to finance and extensive resources required for R\&D projects. Thus, he proposed subsequently that small firms tend rather to imitate than to innovate themselves due 
to high costs of R\&D activity (Schumpeter Mark 2 presented in Schumpeter 1942). Both hypotheses formulated by Schumpeter were tested in numerous studies, for various sectors and economies with contradictory results (Freel 2007; Santarelli and Sterlacchini 1990; Van Dijk et al. 1997; Vaona and Pianta 2008). Recent studies, however, point out that small firms are quite heterogeneous, ranging from highly innovative firms to traditional ones for which the innovation process is irrelevant. As a consequence, the main determinants of innovation in SMEs are proposed to be: sector belonging, the particular nature of innovation and the characteristics of the firm itself, such as size and age (Avermaete et al. 2003; Bhattacharya and Bloch 2004; Ortega-Argilés et al. 2009). Another stream of studies examined the effects of innovation on firm performance (Anwar 2018; Kijkasiwat and Phuensane 2020; Wolff and Pett 2006). Most of the works focus on innovative activity in particular countries (e.g., Hall et al. 2009; Lecerf and Omrani 2019 in Germany; Oke et al. 2007 in the UK; Varis and Littunen 2010 in Finland). However, in this stream of literature, the cross-country studies are relatively rare. Skuras et al. (2008) analyzed product innovation in SMEs from six European countries, while Anwar (2018) identified four clusters of European countries based on the level of intensity of innovative activity. Facing this gap, this study remains focused on the cross-country analysis, by referring to four types of innovation: product, process, management, and sales (organization). In this context, the study aims at answering the first research question:

RQ1: Are there any contingencies between the types of innovations undertaken by SMEs in the cross-country dimension?

\subsection{SMEs and Financing Gap}

Another stream of studies focused on the barriers to innovation, which may be analyzed with regard to: the stages of the innovation process (such as: knowledge, invention, implementation, diffusion, and adaptation), the levels of innovation (microeconomic and macroeconomic barriers), and the nature of factors (financial, personal and organizational, socio-cultural, and legal factors). The variety of barriers to innovation were recently discussed in (Assink 2006; Hueske and Guenther 2015; Madeira et al. 2017). In particular, the access to external financing and the existence of capital constraints that may negatively affect the firms' innovative activity was underlined by Angilella and Mazzù (2015); Colombo and Grilli (2007). Accordingly, the existing empirical evidence shows that the key determinant of the SMEs development is access to sufficient funds. As proved by Kersten et al. (2017), SMEs finance has a positive significant impact on firm performance, capital investment, and employment. However, SMEs often face various problems while searching for new sources of funds. Kumar and Rao (2015) identified the main problems of insufficient funds for SMEs: (1) demand gap, due to the effect of various capital structure determinants, (2) supply gap (limited availability of funds for SMEs), (3) knowledge gap (lack of knowledge on the accessibility of funds, and (4) benevolence gap (unwillingness of financial institutions to provide funds to SMEs). Various financing patterns of SMEs addressing the problem of financing gap were identified and analyzed by Moritz et al. (2016); Ou and Haynes (2006); Whittam and Wyper (2007). Some studies refered exclusively to the debt financing gap (Colombo and Grilli 2007; De Moor et al. 2016; Neely and Auken 2012), while others focused on the equity financing gap (Deffains-Crapsky and Sudolska 2014; Durvy 2007; Papadimitriou and Mourdoukoutas 2002).

Capital structure decisions have been the focus of research attention since the seminal works of Modigliani and Miller (1958). The main theoretical explanation for the capital structure determinants was provided by the pecking order theory (POT). As suggested by Donaldson (1961) and further developed by Myers and Majluf (1984), the observed capital structures reflect the relationship between internally available funds and investment requirements. The POT suggests that companies have a hierarchy of preferences concerning sources of funds. That is the consequence of asymmetric information between management and potential capital providers. This issue may cause firms to avoid raising external equity by issuing new shares. At the same time, while the access to debt may be limited, firms may be forced to postpone or to cancel valuable investment opportunities, including 
innovative ones. In these circumstances, firms prefer internal finance; they try to avoid new equity issues, and their borrowings are a residual between desired investment and the supply of retained earnings. Colombo and Grilli (2007) explained the modified pecking order financing for innovative firms, including private equity financing (from Angel investors and Private Equity/Venture Capital funds) before debt capital. The importance of venture capital for innovative firms is widely discussed in the literature (Da Rin and Penas 2007; Wadhwa et al. 2016; Wu et al. 2019).

Our study, however, addresses the relevance of internal finance, external equity, and debt financing for SMEs, which is consistent with the modified or 'bridged pecking order theory' (BPOT). The BPOT assumes that SMEs move directly from self-funding (internal equity) to external equity (provided by private equity investors) in preference to, or instead of bank finance, as suggested by Whittam and Wyper (2007). The importance of internal finance as the primary source of funds for smaller firms is discussed by $\mathrm{Ou}$ and Haynes (2006), who declared that the significance of external equity for SMEs seems to be overstated. Therefore, based on the BPOT findings and the financing gap facing by SMEs, we may assume that the SMEs' innovative activity is financed first with the internal finance. As a result, the types of innovations undertaken by SMEs may be limited due to the external capital constraints (both in terms of debt and external equity). In this respect, the second question addressed in this study is as follows:

RQ2: Is there any association between the type of innovations in SMEs and the relevance of a given type of financing?

\section{Materials and Methods}

Driven by the relevance of innovation activity of SMEs and the literature evidence on the existence of SMEs financing gap, this study is designed to shed some light on types of innovations of SMEs that perform in the European Union and its relationship with the relevance of a given type of fund. The differences in the implementation of given types of innovation are captured on the cross-country level (RQ1). Further, we investigate the relationships between the types of innovation and the relevance of internal funds, external equity, and debt finance (RQ2).

In the empirical investigations, we rely on the data provided on a regular basis as SAFE (Survey of Access to Finance of Enterprises) reports by the European Commission and European Central Bank. The SAFE dataset consists of aggregated survey results obtained for each of the European Union (EU) member states. In this study, we have focused on SAFE results obtained for five consecutive years in a 5-year time span (2014-2018). Since 2013, the results of the SAFE survey are published annually, but since 2014 in a unified format that allows time comparisons. At the moment of the research investigation, the latest results were available for 2018. The SAFE survey sample includes randomly selected SMEs from each EU member state, from various sectors and of various size (micro, small, and medium-sized enterprises). In 2018, there were over 17,000 survey respondents (SAFE 2018).

For this study, we cluster the EU members states to construct the research sample. First, we grouped the countries following the prevailing classification scheme by distinguishing between the "old" and "new" EU members states, as explained in Table 1. This distinction is guided by the fact that "old" EU member states have a long history of performance as a union and are regarded as better developed, in comparison to the new member states. On the other hand, the "new" member states (in this, the SMEs sector in these countries) have benefited from numerous programs that were aimed at enhancing the removal of disparities (before and shortly after the EU accession). 
Table 1. The clusters of the examined European Union (EU) member states.

\begin{tabular}{|c|c|c|c|}
\hline $\begin{array}{c}\text { Clusters } \\
\text { 1st Demarcation }\end{array}$ & $\begin{array}{c}\text { Sub-Clusters } \\
\text { 2nd Demarcation }\end{array}$ & Countries & Reasoning \\
\hline \multirow[t]{2}{*}{ OLD_EU } & $\begin{array}{l}\text { INNER_C } \\
\text { (inner core) }\end{array}$ & $\begin{array}{l}\text { Belgium } \\
\text { France } \\
\text { Germany } \\
\text { Italy } \\
\text { Luxembourg } \\
\text { The Netherlands } \\
\text { UK }\end{array}$ & $\begin{array}{c}\text { Founders of the EU } \\
\text { and UK as the largest } \\
\text { net contributor }\end{array}$ \\
\hline & $\begin{array}{l}\text { OUTER_C } \\
\text { (outer core) }\end{array}$ & $\begin{array}{c}\text { Austria } \\
\text { Denmark } \\
\text { Finland } \\
\text { Greece } \\
\text { Ireland } \\
\text { Portugal } \\
\text { Spain } \\
\text { Sweden }\end{array}$ & $\begin{array}{l}\text { The remainder 'old' } \\
\text { EU member states }\end{array}$ \\
\hline \multirow[t]{2}{*}{ NEW_EU } & $\begin{array}{c}\text { INNER_P } \\
\text { (inner peripheral) }\end{array}$ & $\begin{array}{l}\text { Cyprus } \\
\text { Estonia } \\
\text { Latvia } \\
\text { Lithuania } \\
\text { Malta } \\
\text { Slovakia } \\
\text { Slovenia } \\
\end{array}$ & $\begin{array}{c}\text { 'New' EU member states } \\
\text { (since } 2004 \text { or later), } \\
\text { in the Eurozone }\end{array}$ \\
\hline & $\begin{array}{c}\text { OUTER_P } \\
\text { (outer peripheral) }\end{array}$ & $\begin{array}{c}\text { Bulgaria } \\
\text { Croatia } \\
\text { Czech Republic } \\
\text { Hungary } \\
\text { Poland } \\
\text { Romania }\end{array}$ & $\begin{array}{c}\text { 'New' EU member states } \\
\text { (since } 2004 \text { or later), } \\
\text { outside the Eurozone }\end{array}$ \\
\hline
\end{tabular}

Secondly, guided by the studies of Bartlett and Prica (2017) and Bruha and Kocenda (2018), we clustered the EU countries into four groups that consider the existence of core and peripheral EU member states. In particular, consistently with Bartlett and Prica (2017), in the cluster of "old" and "new" EU countries, we further distinguished between the inner core, outer core, inner peripheral, and outer peripheral countries. In the cluster of the "old" EU member states, we identified 7 "inner core" countries: the founders of the EU and the UK, as one of the largest net contributors to the EU budget (Kovacevic 2019). In the cluster of the "new" EU countries, we identified 7 "inner peripheral" countries: the members of Eurozone (see the reasoning explained in Table 1). The adopted scheme of clustering the EU countries is justified by the results of prior works related to innovation activity and capital-structure related issues. The Anwar (2018) study confirmed that the majority of the old EU countries are typically innovation leaders, whereas the post-communist countries (that are a majority in outer and inner peripheral EU countries) are low-moderate innovators. Anwar (2018) also addressed the types of innovations (product and process), including SMEs. The Kędzior (2012) study confirmed that there are significant differences in capital structure-related issues between the old and new EU member states.

The list of the examined variables is provided in Table 2. However, it is substantial to explain the methodology behind the SAFE survey and the presentation of its results, as it remains relevant for the design of the empirical investigations performed in this study. The SAFE database presents the percentage structure of SMEs (the respondents) answers for a given question. Moreover, the percentage structure of answers remains aggregated on country level (in other words-it is provided separately for each of the EU member states). In our empirical investigations, we merge two aspects (problems) that were subject to the SAFE study: innovation and sources of funds in SMEs. Within 
the first aspect (innovation), the survey incorporates the set of questions that refer to four areas of improvements implemented by firms in the past year. In this respect, we are able to identify the percentage of companies which declared the implementation of product, process, management, and sales innovations, as explained in Table 2. The second aspect (financing mix) refers to the relevance of a given source of funds. The SAFE survey provides information on the percentage of respondents (SMEs) who declared that a given source of funds was relevant in their activity in the past six months. In this respect, in statistical examinations, we refer to the percentage of firms (SMEs) which declared the relevance of internal funding, external equity, and debt financing, as explained in Table 2.

In the empirical investigations, we use the non-parametric methods, due to the nature of the available data. In particular, to examine the differences on country-level (in accordance with the defined clusters), the non-parametric ANOVA is used (Kruskal-Wallis test). The relationships of SMEs innovation and the use of particular sources of funds are captured by the Rho-Spearman correlations.

Table 2. The definitions of the examined variables.

\begin{tabular}{ll}
\hline \multicolumn{1}{c}{ Variable } & \multicolumn{1}{c}{ Definition } \\
\hline Product & $\begin{array}{l}\text { Types of SMEs innovation } \\
\text { significant improvements in products or services within the past year. }\end{array}$ \\
\hline Process & $\begin{array}{l}\text { The percentage of companies which declared that they introduced } \\
\text { significant improvements of production process or methods within the } \\
\text { past year. }\end{array}$ \\
\hline Management & $\begin{array}{l}\text { The percentage of companies which declared that they introduced a new } \\
\text { organization of management within the past year. }\end{array}$ \\
\hline Sales & $\begin{array}{l}\text { The percentage of companies which declared that they introduced a new } \\
\text { way of selling goods or services. }\end{array}$ \\
\hline INTERNAL FINANCING & \multicolumn{1}{c}{ Relevance of SMEs financing } \\
\hline EXTERNAL EQUITY & $\begin{array}{l}\text { The percentage of surveyed companies which declared the relevance of } \\
\text { used over the past } 6 \text { months or are considered to be used in the future). }\end{array}$ \\
\hline DEBT & $\begin{array}{l}\text { The percentage of surveyed companies which declared the relevance of } \\
\text { external sources of equity (equity capital was used over the past } 6 \text { months } \\
\text { or is considered to be used in the future). }\end{array}$ \\
\hline $\begin{array}{l}\text { The percentage of surveyed companies which declared the relevance of } \\
\text { debt (debt was used over the past } 6 \text { months or is considered to be used in } \\
\text { the future) }\end{array}$
\end{tabular}

\section{Results and Discussion}

\subsection{SMEs Innovations across the EU}

In Appendix A, we present the figures with data on the percentage share of SMEs, which declared the implementation of a given type of innovation between 2014 and 2018 (product, process, management, or sales), in accordance with the assumed clusters of the EU member states. The data indicate that in the case of the implementation of product, process, and sales innovations, the situation could be judged as comparable. The percentage of SMEs which declared the implementation of product, process, and sales innovations was slightly lower in inner core EU countries, in comparison to the remaining core countries. In the group of the old EU countries, Finland is clearly in the leading position. Moreover, in the cluster of the old EU countries in the majority of the countries, peak levels of product and process innovations were observable until 2017, with a visible drop in 2018. A similar pattern of changes was observable in the cluster of new EU countries (2014-2017), however with a slight improvement in 2018. In the inner peripheral countries, the lowest percentage of SMEs that declared 
the implementation of the product, or process innovations was in Estonia, whereas in the cluster of outer peripheral countries-in Hungary. In the remaining new EU countries, the percentage of SMEs that declared the implementation of product or process innovations could be judged as comparable, with the most dynamic changes in Cyprus, Latvia, and Malta (only for process innovations). Similar conclusions could be drawn concerning sales innovations, with a leading position in Cyprus and Romania. Cyprus and Romania are also leading in the implementation of management innovations (Figure A3). However, in the case of old EU countries, the situation is different as compared to product, process, and sales innovations. First, a slightly higher percentage of innovative SMEs operating in the cluster of inner core EU countries is observable, as compared to the outer core ones. In the old EU countries, Greece was in a leading position in the implementation of management innovations, as declared by SMEs. The data also indicate that in the majority of countries, the declared level of management innovations remained unchanged between 2017 and 2018.

The initial observations on the overall trends and differences between the declared level of the implementation of innovation in European SMEs (Appendix A) justify the examination of the statistical relevance of these differences, within the defined clusters of countries and consistently with the first research question (RQ1). In Table 3, we present the results of non-parametric tests that have confirmed that there are statistically significant differences between the defined clusters of countries, concerning the percentage of SMEs that declared the implementation of the product, management, and sales innovation, but not the process innovations. Within the comparisons between new and old EU countries, the mean ranks of the U Mann-Whitney test (Figure 1) indicate that in the cluster of new EU countries, a higher percentage of SMEs declared the implementation of product innovations, as compared to the old EU countries. However, we observe a contrary situation in the case of management and sales innovations. The percentage of SMEs, which declared the implementation of management and sales innovations was significantly higher in the old EU countries, as compared to the new ones.

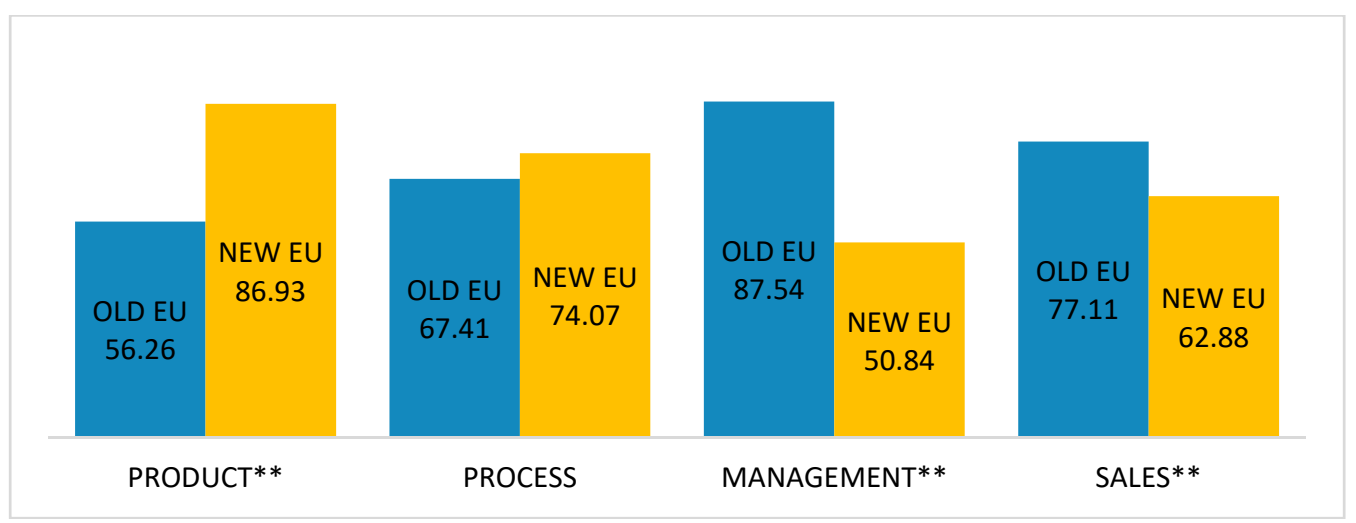

Figure 1. Mean ranks of U Mann-Whitney test for differences in the declared implementation of innovation between the clusters of old and new EU member states. Notes: statistically significant differences at ${ }^{* *} \alpha=0.05$.

The Kruskal-Wallis test indicates the overall differences between the four clusters of EU countries. Thus, to detects which specific groups of countries differ significantly, the post hoc tests were performed (see Table 3). In the case of product innovations, the post hoc tests have confirmed that there are statistically significant differences between the inner core EU countries, as compared to the remainder clusters. The analysis of mean ranks of the Kruskal-Wallis test, illustrated in Figure 2 indicates that the percentage of SMEs that declared the implementation of product innovation was significantly lower in inner core countries, as compared to the remainder clusters. In the case of management innovation, statistically significant differences were observed in several dimensions. First of all, the post hoc tests and the ranks of the Kruskal-Wallis test indicate that the percentage of SMEs which declared the implementation of management innovation was significantly higher in the cluster of 
outer core EU countries, in comparison to the clusters of the outer and inner peripheral. Moreover, the percentage of SMEs which declared the implementation of innovation in management was significantly higher in the cluster of inner core countries, in comparison to the clusters of inner and outer peripheral (Figure 2). Finally, in the case of sales innovation, the statistically significant differences were confirmed only between the cluster of the outer core EU countries and the cluster of outer peripheral countries (significantly higher percentage of SMEs declared the implementation of innovations in sales in the cluster of the outer core, as compared to the cluster of outer peripheral EU countries).

Table 3. The differences between the clusters of countries concerning innovation in SMEs.

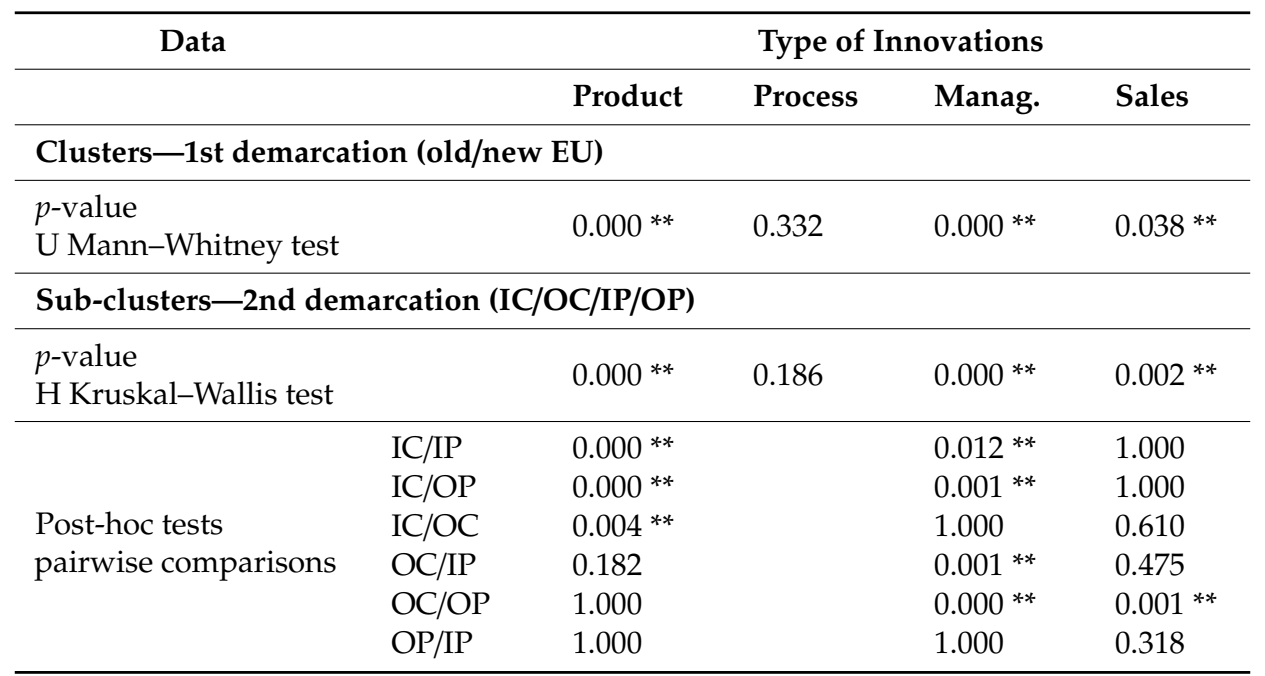

Notes: statistically significant at ${ }^{* *} \alpha=0.05$; symbols: IC-inner core, OC-outer core, IP-inner peripheral, $\mathrm{OP}$-outer peripheral.

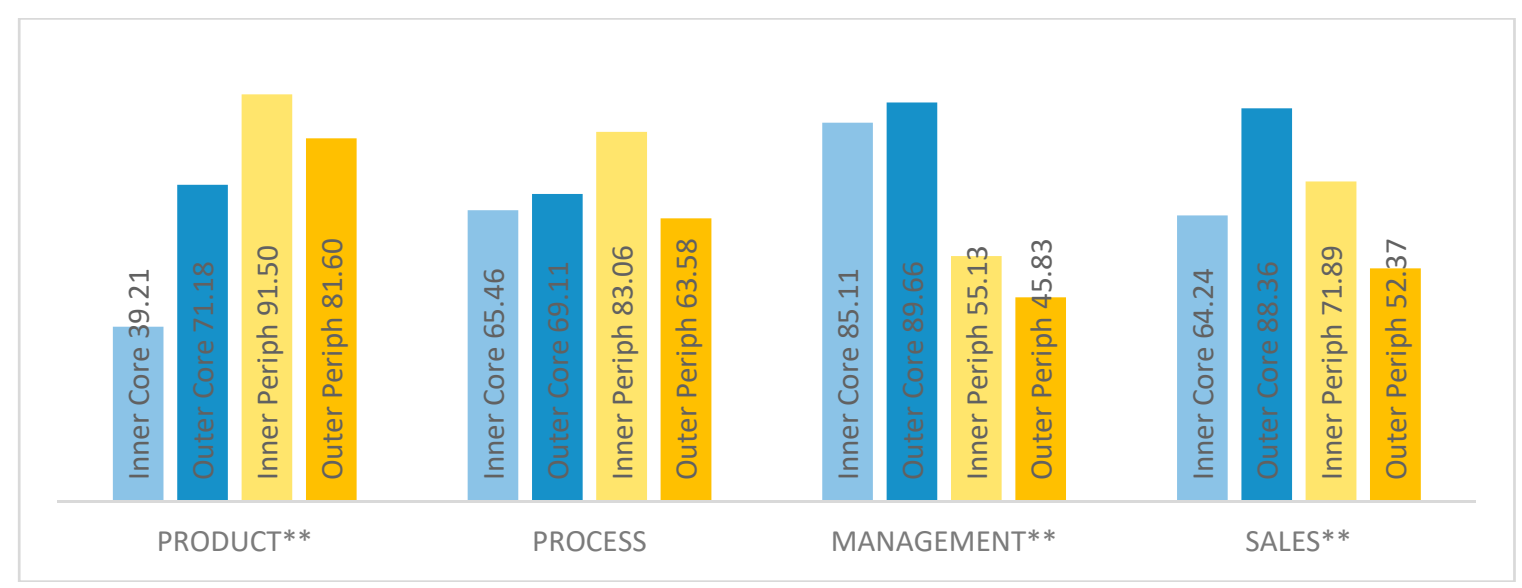

Figure 2. Mean ranks of the Kruskal-Wallis test for differences in the declared implementation of innovation between the sub-clusters of the EU countries. Notes: statistically significant differences at ** $\alpha=0.05$.

We additionally examined the possible co-existence between the types of innovations most frequently undertaken by the SMEs. In Table 4, we present the Rho-Spearman correlation coefficients to capture the associations between the percentage of the European SMEs, which declared the implementation of various types of innovations, broken by the clusters of analyzed countries. 
Table 4. Correlations between a percentages of the European SMEs which declared the implementation of innovations.

\begin{tabular}{|c|c|c|c|c|}
\hline & \multicolumn{4}{|c|}{ Declared Types of Innovations } \\
\hline & Product & Process & Management & Sales \\
\hline \multicolumn{5}{|l|}{ Old EU } \\
\hline Product & 1 & & & \\
\hline Process & $0.676^{* *}$ & 1 & & \\
\hline Management & 0.077 & $0.282 *$ & 1 & \\
\hline Sales & $0.653 * *$ & $0.714^{* *}$ & $0.356^{* *}$ & 1 \\
\hline \multicolumn{5}{|l|}{ New EU } \\
\hline Product & 1 & & & \\
\hline Process & $0.675^{* *}$ & 1 & & \\
\hline Management & $0.460 * *$ & $0.529 * *$ & 1 & \\
\hline Sales & $0.464^{* *}$ & $0.455^{* *}$ & $0.744^{* *}$ & 1 \\
\hline \multicolumn{5}{|l|}{ Inner Core } \\
\hline Product & 1 & & & \\
\hline Process & $0.432 * *$ & 1 & & \\
\hline Management & 0.206 & $0.744^{* *}$ & 1 & \\
\hline Sales & $0.395 *$ & $0.648^{* *}$ & $0.425 *$ & 1 \\
\hline \multicolumn{5}{|l|}{ Outer Core } \\
\hline Product & 1 & & & \\
\hline Process & $0.839 * *$ & 1 & & \\
\hline Management & -0.033 & -0.011 & 1 & \\
\hline Sales & $0.667 * *$ & 0.773 ** & $0.351 *$ & 1 \\
\hline \multicolumn{5}{|l|}{ Inner Peripheral } \\
\hline Product & 1 & & & \\
\hline Process & $0.616^{* *}$ & 1 & & \\
\hline Management & $0.363 *$ & 0.323 & 1 & \\
\hline Sales & 0.310 & 0.100 & $0.628^{* *}$ & 1 \\
\hline \multicolumn{5}{|l|}{ Outer Peripheral } \\
\hline Product & 1 & & & \\
\hline Process & $0.761^{* *}$ & 1 & & \\
\hline Management & $0.579 * *$ & $0.849 * *$ & 1 & \\
\hline Sales & $0.609 * *$ & $0.821^{* *}$ & $0.887^{* *}$ & 1 \\
\hline
\end{tabular}

Notes: statistically significant at ${ }^{* *} \alpha=0.01 ;{ }^{*} \alpha=0.05$.

The data presented in Table 4 indicate that in general, in the cluster of the old EU countries, there were statistically significant correlations between all types of innovations, except for product and management. It suggests that the undertakings of various types of innovations co-existed in the surveyed SMEs that perform in the old EU member states. This pattern of interdependencies is repeated in the sub-clusters of inner and outer core countries. However, in the case of the cluster of inner core countries, the correlation coefficients between product innovation and process and sales innovations are visibly lower, as compared to the cluster of outer core countries. In the cluster of new EU countries, there are statistically significant correlations between the implementation of all types of innovations, and this pattern is also observable in the sub-cluster of outer peripheral countries, with visibly higher correlation coefficients. In the case of inner peripheral countries, the statistically significant correlations are observable only between the following pairs of innovations: process and product, management and sales, as well as management and product. These observations clearly indicate that the co-existence of the implementation of various innovations was higher in the cluster of outer peripheral countries (for statistically significant correlation coefficients). That can be explained by the 'spiral of innovation' phenomenon, which describes the relationship between different types of innovations: one successful innovation (e.g., product innovation) begets the other (e.g., process 
innovation). One type of innovation generates demand on the other, as well as it provides solutions that can be used to create new developments.

\subsection{Types of SMEs Innovations and Sources of Funds}

The second aspect of the empirical investigations was concerned with the analysis of the associations between the percentage of SMEs that declared the implementation of a given type of innovation and the percentage of SMEs that declared the relevance of a given source of financing (RQ2). In this respect, we may track the possible relevance of a given type of financing to the implementation of innovations. In Table 5, we present the Rho-Spearman correlation matrix, broken by the analyzed clusters of the EU countries.

Table 5. Correlations between declared type of innovation and relevance of a given source of funds.

\begin{tabular}{|c|c|c|c|c|}
\hline & Product & Process & Management & Sales \\
\hline \multicolumn{5}{|l|}{ Old EU } \\
\hline Internal & $0.252 *$ & 0.112 & $-0.277^{*}$ & 0.019 \\
\hline External Equity & 0.042 & -0.072 & -0.220 & -0.055 \\
\hline Debt & 0.200 & $0.451 * *$ & $0.328^{* *}$ & $0.464^{* *}$ \\
\hline \multicolumn{5}{|l|}{ New EU } \\
\hline Internal & 0.194 & $0.255 *$ & 0.216 & 0.184 \\
\hline External Equity & 0.218 & $0.482^{* *}$ & $0.261 *$ & 0.241 \\
\hline Debt & $0.396^{* *}$ & 0.431 ** & $0.458^{* *}$ & $0.363^{* *}$ \\
\hline \multicolumn{5}{|l|}{ Inner Core } \\
\hline Internal & 0.321 & 0.220 & 0.185 & 0.139 \\
\hline External Equity & -0.148 & -0.016 & -0.080 & 0.081 \\
\hline Debt & -0.145 & 0.364 * & 0.373 * & 0.290 \\
\hline \multicolumn{5}{|l|}{ Outer Core } \\
\hline Internal & 0.205 & 0.046 & $-0.591 * *$ & 0.205 \\
\hline External Equity & -0.023 & -0.120 & $-0.314 *$ & -0.023 \\
\hline Debt & $0.462 * *$ & $0.511 * *$ & 0.304 & $0.462 * *$ \\
\hline \multicolumn{5}{|l|}{ Inner Peripheral } \\
\hline Internal & 0.257 & 0.156 & 0.097 & 0.238 \\
\hline External Equity & 0.150 & $0.366^{*}$ & 0.078 & 0.027 \\
\hline Debt & 0.331 & 0.326 & $0.551^{* *}$ & $0.526^{* *}$ \\
\hline \multicolumn{5}{|l|}{ Outer Peripheral } \\
\hline Internal & 0.057 & 0.338 & 0.339 & 0.100 \\
\hline External Equity & 0.219 & $0.573^{* *}$ & $0.534^{* *}$ & 0.417 * \\
\hline Debt & $0.465 * *$ & $0.518^{* *}$ & 0.212 & 0.152 \\
\hline
\end{tabular}

Notes: statistically significant at ${ }^{* *} \alpha=0.01 ;{ }^{*} \alpha=0.05$.

In the cluster of the old EU countries, there are statistically significant correlations between the percentage of SMEs that declared the implementation of process, management, and sales innovations and the relevance of debt financing. It suggests that debt finance remains a prime source of funds for these types of innovations in the SMEs performing in the old EU countries. However, if we consider the sub-clusters of the old EU countries (inner and outer core countries), the statistically significant correlations were observed only in the case of debt financing and management and process innovation (inner core), as well as between debt financing and the product, process, and sales innovation (outer core).

In the cluster of new EU countries, the statistically significant correlations are observable between debt financing and the implementation of all types of innovations. In addition, the declaration on the relevance of external equity financing was correlated with the declarations on the implementation of process and management innovations, while internal financing was correlated with the process innovations. 
In general, if we consider the correlations in the sub-clusters of new EU countries (inner and outer peripheral), the statistically significant correlations were obtained only for debt financing and management and sales innovations (inner peripheral), as well as for debt financing and product and process innovations (outer peripheral). Interestingly, the relevance of equity financing was correlated with the declaration on the implementation of process innovations (both in inner and outer peripheral) as well as management and sales innovations (outer peripheral).

The obtained results clearly indicate that on the level of sub-clusters of the EU countries, there is no unified pattern of correlations between the relevance of a given source of financing and a given type of innovation. Nevertheless, debt financing seems to be a primary source of financing innovation in all clusters of countries, and external equity remains relevant only in the case of new EU countries. This may lead to the conclusion that different financing mechanisms were developed in different countries. In some countries, the main source of finance for innovative SMEs comes from the banking sector, in others-from the private equity capital providers. Possibly, our observations are related to the financial support and arrangements offered within the equity-related programs directed to SMEs operating in the new European member states.

\section{Conclusions}

This study was designed to capture the cross-country differences in the types of innovations undertaken by European SMEs (RQ1) and the relationship between the types of innovations and relevance of given types of funding (RQ2). The empirical investigation has found out that there are significant differences in SMEs innovations if we consider the product, management, and sales innovations. However, the directions of these differences are heterogeneous. The larger scale of product innovations was observed in the new EU member states, while the larger scale of management and sales innovations was identified in the old EU member states. If we consider the sub-clusters of EU countries (inner/outer core and inner/outer peripheral), a similar pattern was confirmed. The SMEs from the inner core of the old EU member states are significantly least involved in the product innovations, at the same time, the SMEs form the inner core and outer core EU countries are the leaders in the management innovations. Simultaneously, the SMEs from outer and inner peripheral countries are less involved in management innovations.

This evidence suggests that the types of innovations undertaken by the SMEs may be linked to the general level of economic development and innovative activity in particular countries. The SMEs from the new member states try to catch up with SMEs from countries with a higher level of development, focusing on product innovations. On the other hand, more developed economies create a favorable environment for further improvements beyond product innovations. The importance of the regional factors in the innovation process was underlined by Varis and Littunen (2010). In addition, the different scale of innovative activity in different European countries was noticed by Anwar (2018). In this respect, further inquiries should be placed to detect the drivers of SMEs innovativeness, on the cross-country level. In particular, the relevance of dynamic development of IT technology shall be addressed, in this, the open access to knowledge and the increasing popularity of the open innovation concept.

This study has also confirmed the contingencies between the types of innovations undertaken by SMEs in each cluster of the European countries. These contingencies are most visible in the case of the cluster of the old EU countries, as well as in the outer peripheral cluster. It was found that various types of investment are accompanying undertaken innovations, thus various types of innovations co-exist, although they require different inputs and strategies as suggested by Vaona and Pianta (2008) and are characterized by different degrees of persistency as noticed by Tavassoli and Karlsson (2015). That relationship is explained by 'the spiral of innovation' phenomenon, according to which, one successful innovation provides the opportunity to create another one.

The second aspect subject to this study and addressed in the second research question (RQ2-the analysis of the associations between the type of innovation and a given type of financing) provided mixed results. Although debt capital was identified as the prime source of financing innovations in 
several sub-clusters of countries, there is no unified pattern of correlations between the relevance of a given source of financing and given type of innovation. These results are inconsistent with our earlier assumption about the importance of internal finance, as suggested by the BPOT. They are also in contrast to the earlier findings that innovative firms are more likely to be financed by equity than debt (Hall 2010). On the other hand, Kerr and Nanda (2015) noticed the growing importance of debt financing related to innovation. It suggests that different financing mechanisms were developed in different countries to facilitate SMEs access to finance for innovative activity, which was addressed by Moritz et al. (2016). However, further studies are needed to confirm this supposition. In particular, further studies shall revise the relevance of debt financing, with reference to the domination of banking sector in the financial system, which is typical in numerous European countries. On the other hand, in the case of SMEs, the external equity comes mostly from the private equity market, of which development is one of the priorities of the European Union strategy, focusing on the sustainable growth and innovation.

The results of this study contribute to the ongoing debate on the SMEs financing gap, as linked to their innovative activities (Hottenrott and Peters 2012; Lee et al. 2015; Vasilescu 2014). From an applicative point of view, these results may support the design of system intervention mechanisms that are implemented to reduce the existence of the SME financing gap. As the SMEs operating in various countries remain focused on various types of innovations, the country settings seem to be relevant for the directions of innovations undertaken by the SMEs. In finance-oriented contexts, the system intervention mechanisms should be multivariate and allow flexible design of SMEs financing mix. Moreover, it seems that the system interventions mechanisms should not pursue a defined financing mix for the implementation of a given type of innovation. The core element of these mechanisms should be based on the alternative market-based financing instruments, which are crucial for access to the long-term sources of funds, as noted by Goujard and Guérin (2018).

The main limitation of this study is the nature of the SAFE survey data. Surveys data are always exposed to the risk of bias. In this case, the conclusions are finally driven concerning the SMEs' self-reported (and thus subjective) information. However, as the SAFE survey is repeated continuously (the EU initiative), the risk of bias seems limited. Nevertheless, this study signals a need to perform further investigations that could potentially enrich the evidence on innovative activity of SMEs and financing (capital structure) considerations. In particular, by referring to other possible proxies of innovation in SMEs, the direct associations with the existing SMEs capital structures could be addressed. Such an approach, however, needs a detailed study related to balance sheet entries and annual reports. Further inquiries shall also be placed to better explain the possible reasons behind the differences in types of undertaken innovation in the country-oriented contexts.

Author Contributions: The contribution of co-authors is $40 \%$ for J.B.; $40 \%$ for M.W.-K.; and $20 \%$ for J.T. Conceptualization J.B. and M.W.-K.; literature review section J.B.; results and discussion section; statistical calculations M.W.-K. and J.T.; material and methods section M.W.-K.; writing and editing J.B. and M.W.-K. All authors have read and agreed to the published version of the manuscript.

Funding: This research received no external funding.

Acknowledgments: We gratefully acknowledge the insightful comments provided by three anonymous Reviewers of our paper.

Conflicts of Interest: The authors declare no conflict of interest. 


\section{Appendix A}

PANEL A. INNER CORE

ロ $2014 \quad 2015 \square 2016 \square 2017 \square 2018$

$60 \%$
$50 \%$
$40 \%$
$30 \%$
$20 \%$
$10 \%$
$0 \%$

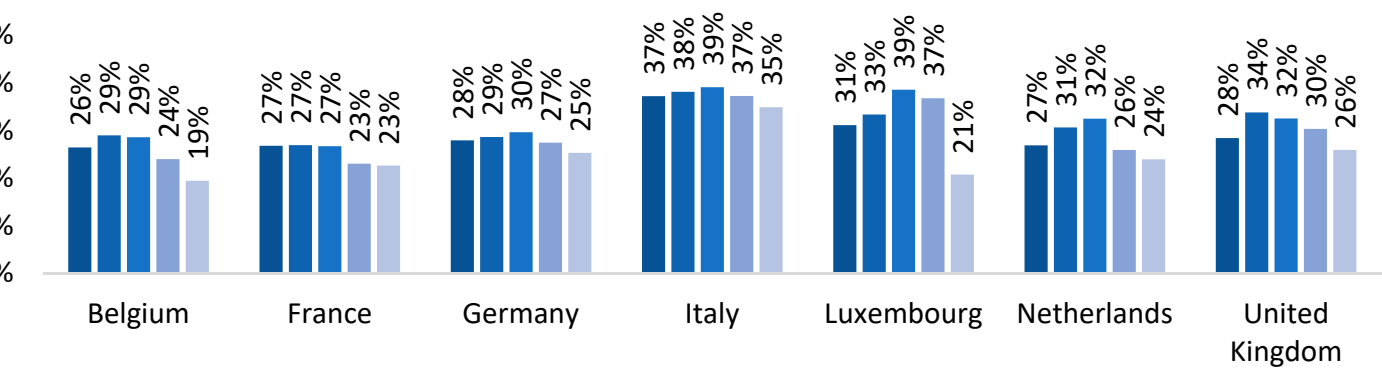

PANEL B. OUTER CORE

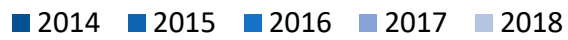

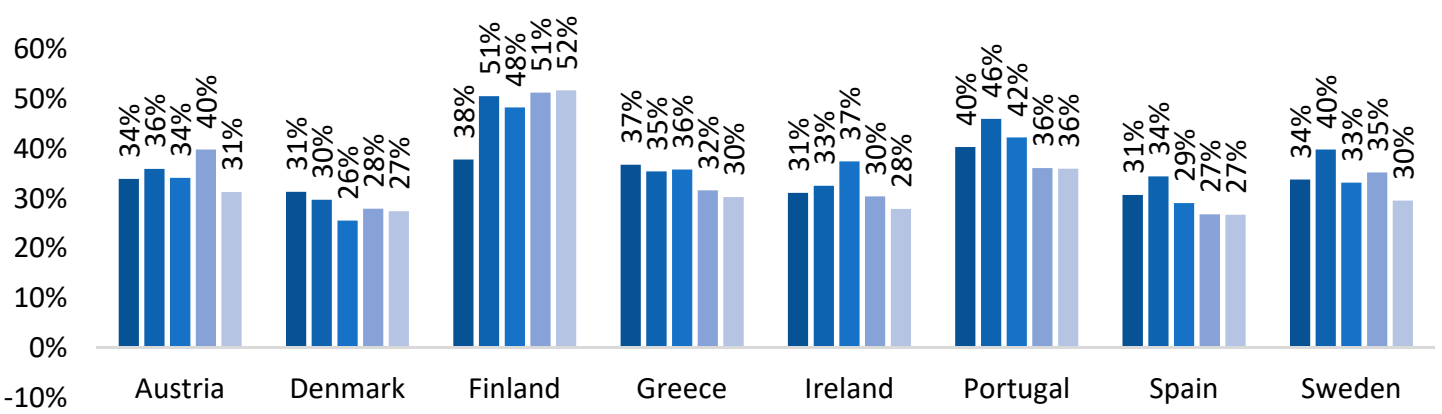

PANEL C. INNER PERIPHERAL

$\square 2014 \quad 2015 \quad \square 2016 \quad 2017 \square 2018$

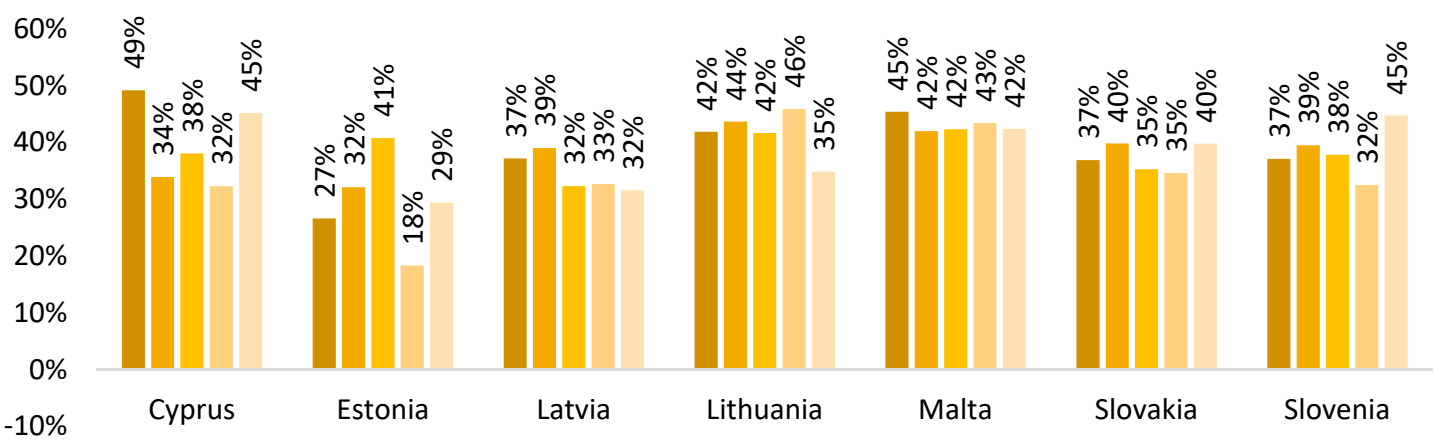

PANEL D. OUTER PERIPHERAL

$\square 2014 \square 2015 \quad 2016 \quad 2017 \quad 2018$

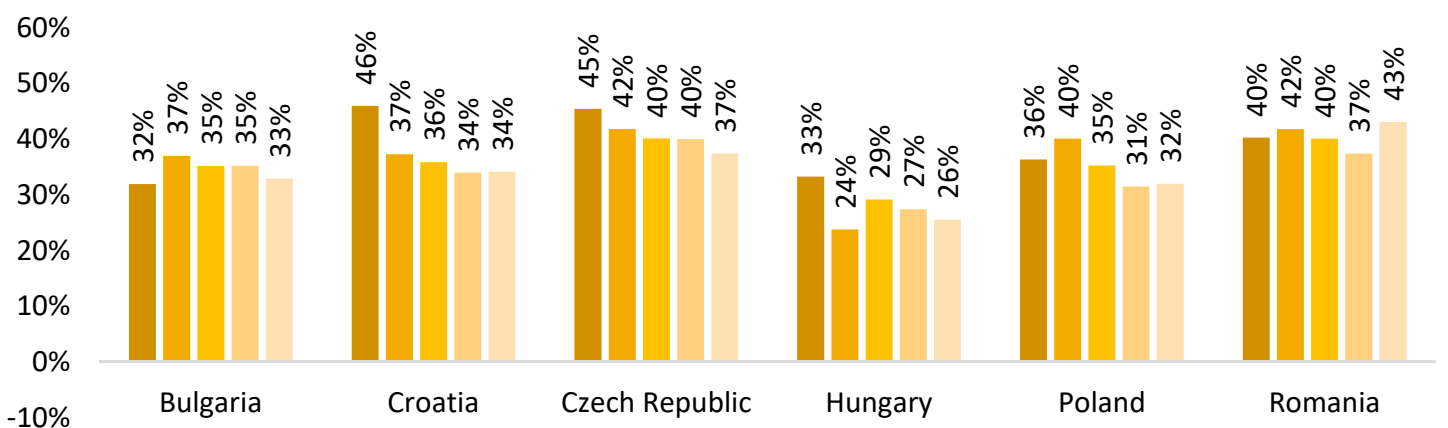

Figure A1. Percentage share of SMEs which declared the implementation of product innovations by country. Source: Own study. 
PANEL A. INNER CORE

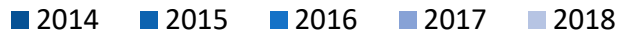

$50 \%$

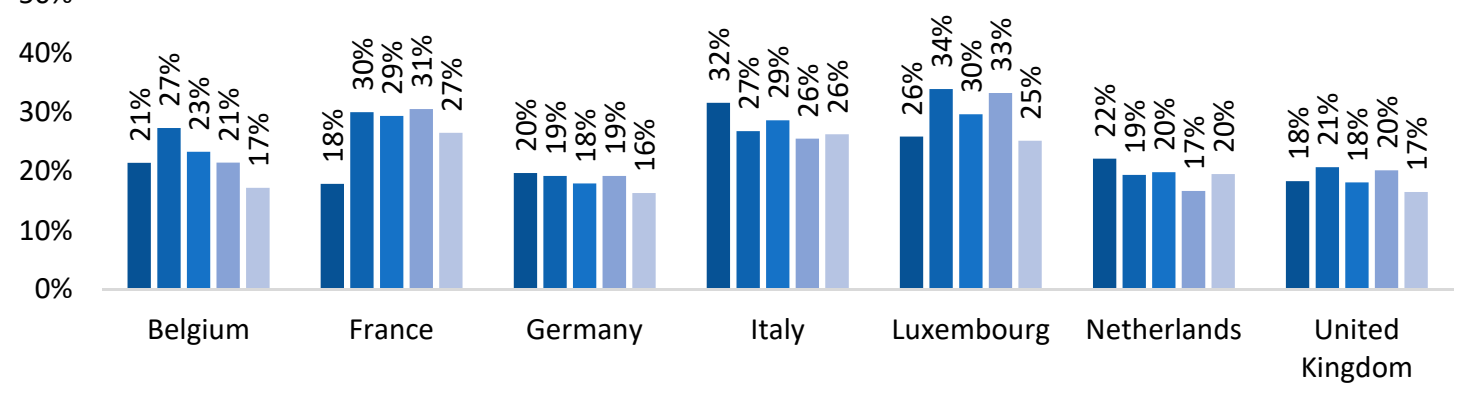

PANEL B. OUTER CORE

$\square 2014 \square 2015 \quad \square 2016 \quad \square 2017 \square 2018$

$50 \%$

$40 \%$

$30 \%$

$20 \%$

$10 \%$

$0 \%$

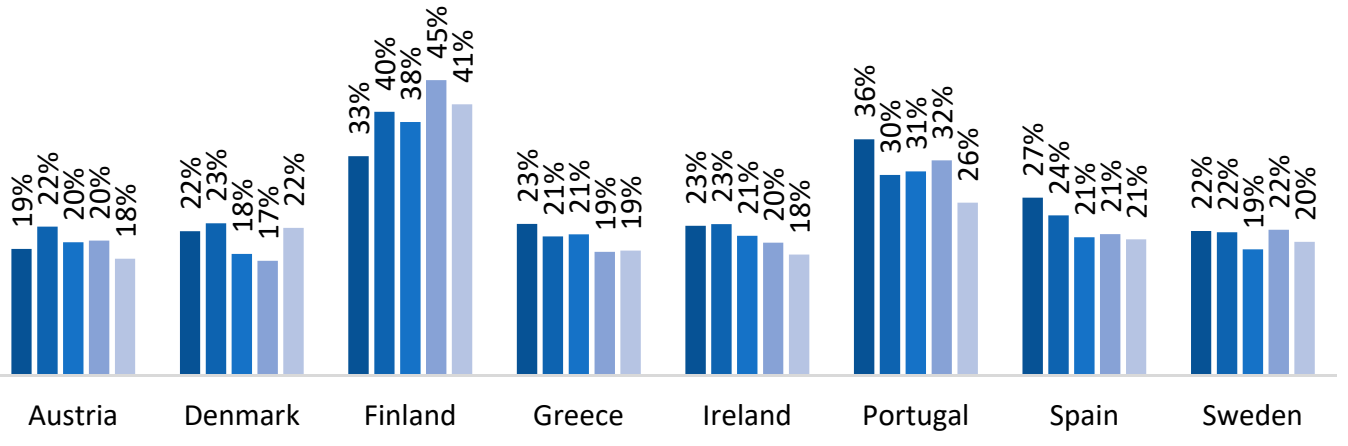

PANEL C. INNER PERIPHERAL

$\square 2014 \square 2015 \square 2016 \square 2017 \square 2018$

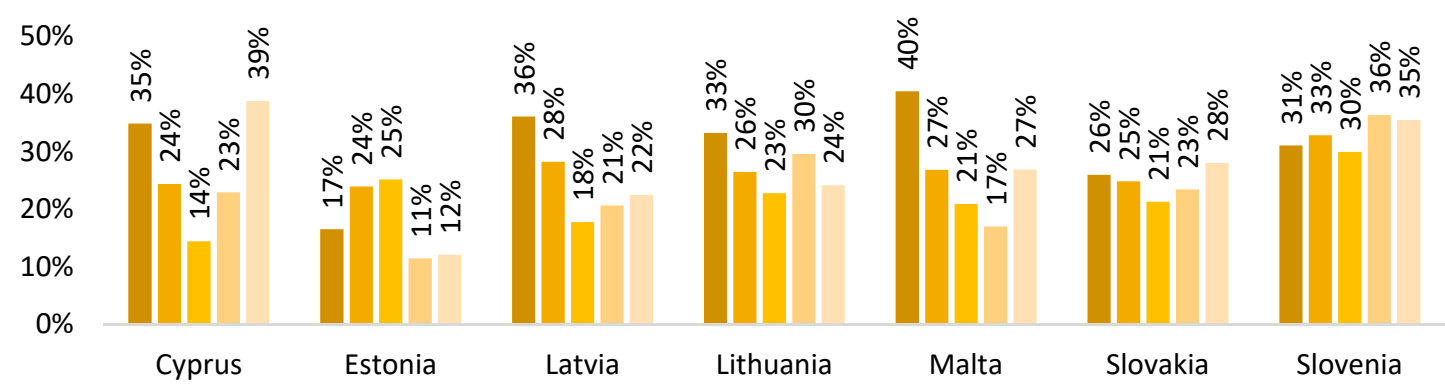

PANEL D. OUTER PERIPHERAL

$\square 2014 \square 2015 \square 2016 \square 2017 \quad 2018$

$50 \%$

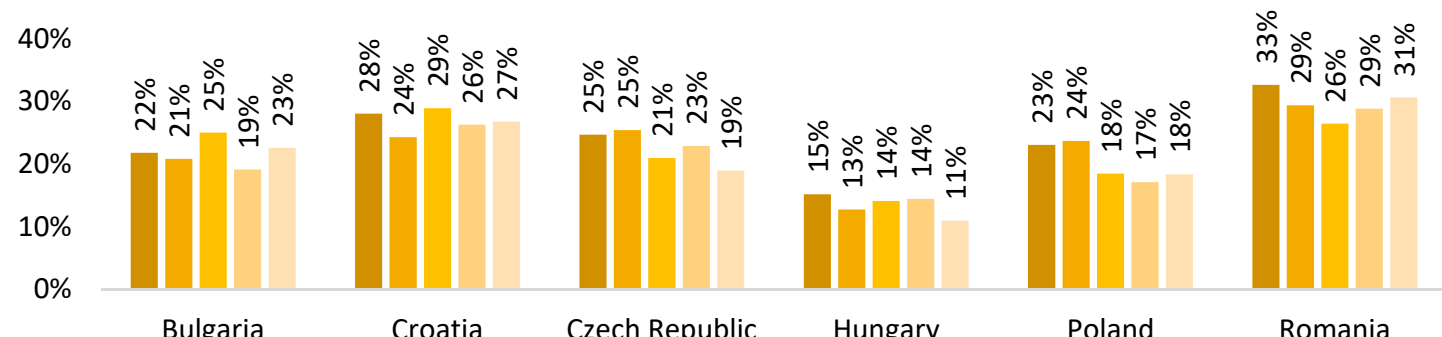

Figure A2. Percentage share of SMEs which declared the implementation of process innovations by country. Source: Own study. 
PANEL A. INNER CORE

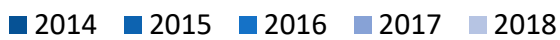

$60 \%$

$50 \%$

$40 \%$

$30 \%$

$20 \%$

$10 \%$

$0 \%$

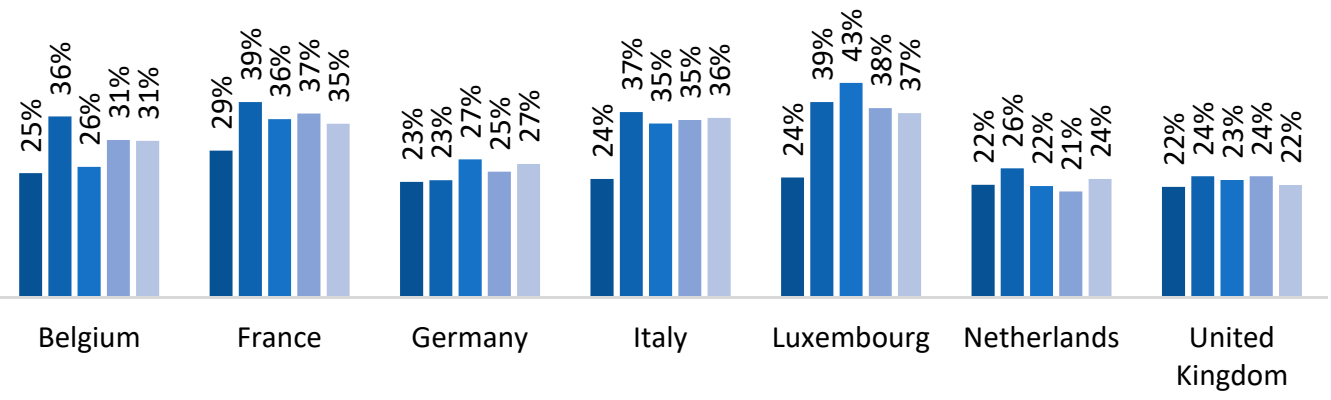

PANEL B. OUTER CORE

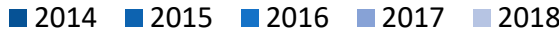

$60 \%$

$50 \%$

$40 \%$

$30 \%$

$20 \%$

$10 \%$

$0 \%$

$-10 \%$
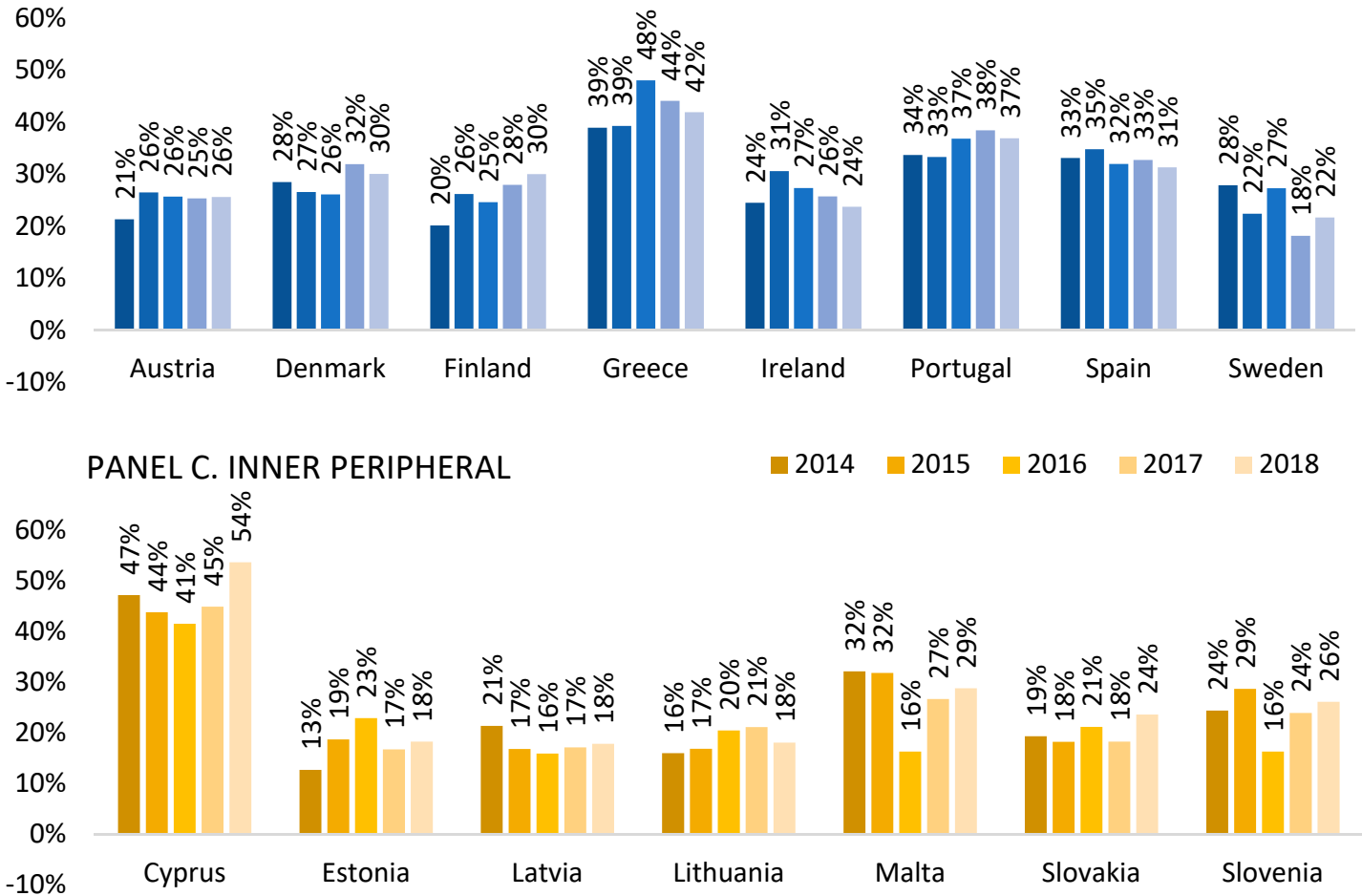

PANEL D. OUTER PERIPHERAL

$\square 2014 \square 2015 \square 2016 \square 2017 \quad 2018$

$60 \%$

$50 \%$

$40 \%$

$30 \%$

$20 \%$

$10 \%$

$0 \%$

$-10 \%$

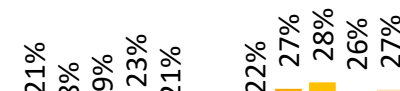

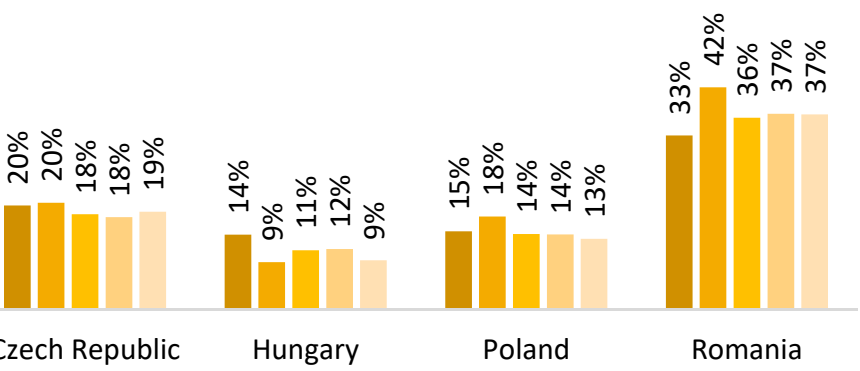

Figure A3. Percentage share of SMEs which declared the implementation of management innovations by country. Source: Own study. 
PANEL A. INNER CORE

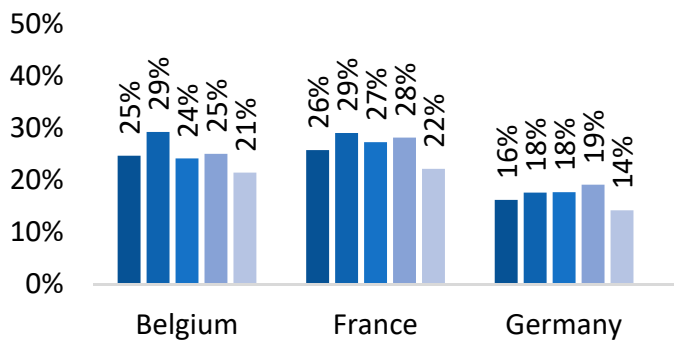

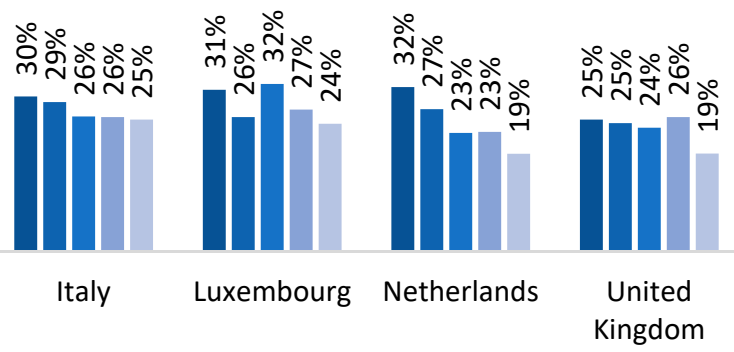

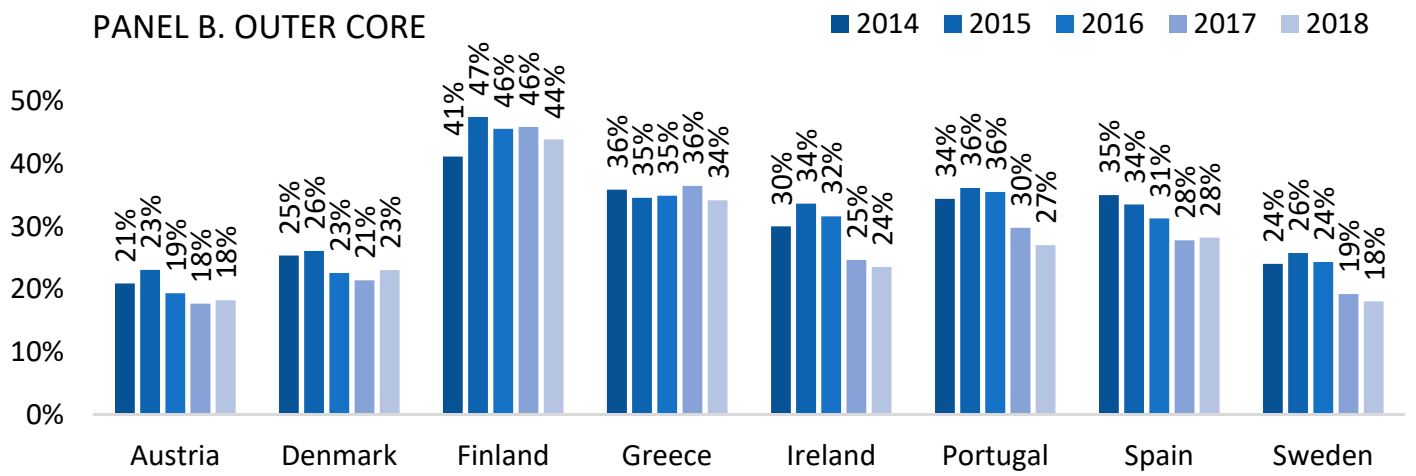

PANEL C. INNER PERIPHERAL

$\square 2014 \square 2015 \square 2016 \square 2017 \quad 2018$

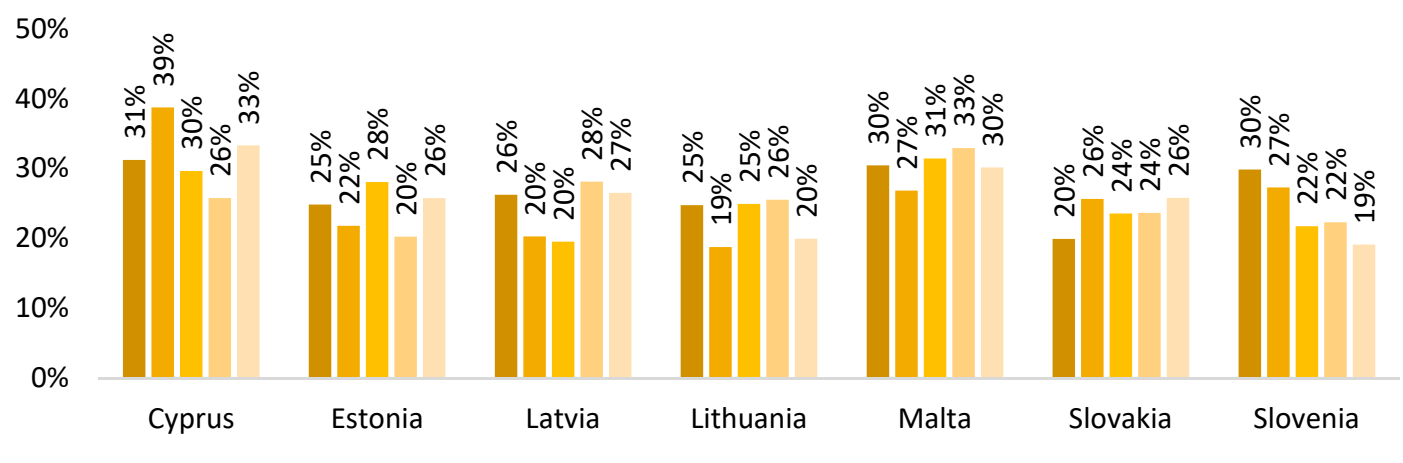

PANEL D. OUTER PERIPHERAL

$\square 2014 \square 2015 \square 2016 \square 2017 \square 2018$

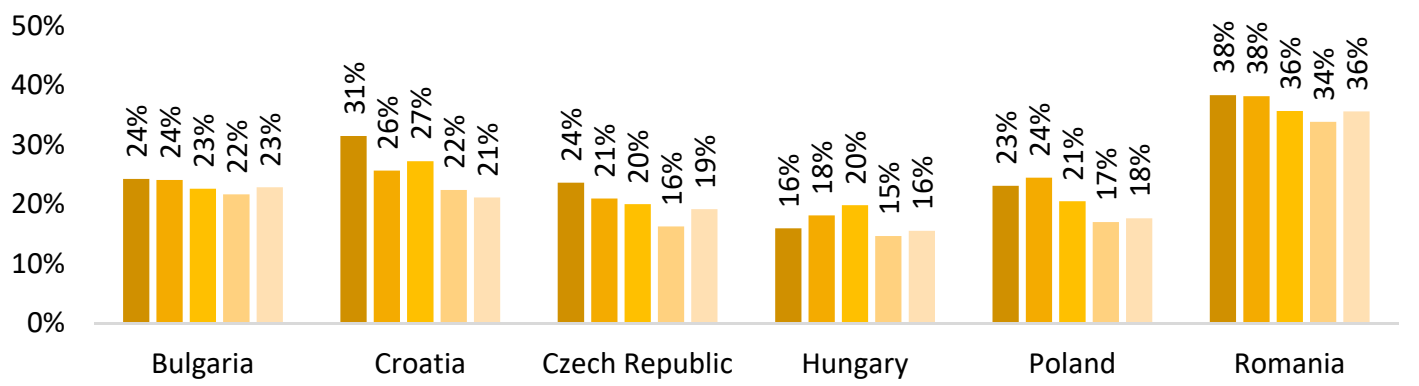

Figure A4. Percentage share of SMEs which declared the implementation of sales innovations by country. Source: Own study. 


\section{References}

Angilella, Silvia, and Sebastiano Mazzù. 2015. The financing of innovative SMEs: A multicriteria credit rating model. European Journal of Operational Research 244: 540-54. [CrossRef]

Anwar, Muhammad. 2018. Business model innovation and SMEs performance: Does competitive advantage mediate? International Journal of Innovation Management 22: 1-31. [CrossRef]

Assink, Marnix. 2006. Inhibitors of disruptive innovation capability: A conceptual model. European Journal of Innovation Management 9: 215-33. [CrossRef]

Avermaete, Tessa, Jacques Viaene, Eleanor J. Morgan, and Nick Crawford. 2003. Determinants of innovation in small food firms. European Journal of Innovation Management 6: 8-17. [CrossRef]

Baldock, Robert, and Colin Mason. 2015. Establishing a new UK finance escalator for innovative SMEs: The roles of the Enterprise Capital Funds and Angel Co-Investment Fund. Venture Capital 17: 59-86. [CrossRef]

Baregheh, Anahita, Jennifer Rowley, Sally Sambrook, and Dafydd Davies. 2012. Food sector SMEs and innovation types. British Food Journal 114: 1640-53. [CrossRef]

Bartlett, William, and Ivana Prica. 2017. Interdependence between Core and Peripheries of the European Economy: Secular Stagnation and Growth in the Western Balkans. European Journal of Comparative Economics 14: 123-39. [CrossRef]

Bhattacharya, Mita, and Harry Bloch. 2004. Determinants of innovation. Small Business Economics 22: 155-62. [CrossRef]

Beck, Thorsten, Asli Demirguc-Kunt, and Ross Levine. 2005. SMEs, growth, and poverty: Cross-country evidence. Journal of Economic Growth 10: 199-229. [CrossRef]

Boer, Harry, and Willem E. During. 2001. Innovation, what innovation? A comparison between product, process and organizational innovation. International Journal of Technology Management 22: 83-107. [CrossRef]

Bruha, Jan, and Evžen Kocenda. 2018. Financial stability in Europe. Banking and sovereign risk. Journal of Financial Stability 36: 305-21. [CrossRef]

Colombo, Massimo G., and Luca Grilli. 2007. Funding gaps? Access to bank loans by high-tech start-ups. Small Business Economics 29: 25-46. [CrossRef]

Da Rin, Marco, and MarÃ-a Fabiana Penas. 2007. The effect of venture capital on innovation strategies (No. w13636). National Bureau of Economic Research. [CrossRef]

Deffains-Crapsky, Catherine, and Agata Sudolska. 2014. Radical innovation and early stage financing gaps: Equity-based crowdfunding challenges. Journal of Positive Management 5: 3-19. [CrossRef]

De Moor, Lieven, M. Wieczorek-Kosmala, and Joanna Błach. 2016. SME Debt Financing Gap: The Case of Poland. Transformations in Business Economics 15: 274-91.

Donaldson, Gordon. 1961. Corporate Debt Capacity: A Study of Corporate Debt Policy and Determination of Corporate Debt Capacity. Working Paper. Boston: Harvard Graduate School of Management.

Durvy, Mr Jean-Noel. 2007. Equity Financing for SMEs: The Nature of the Market Failure. In The SME Financing Gap, Proceedings of the Brasilia Conference, Brasilia, 27-30 March 2006. Paris: OECD Publishing, vol. II.

Goujard, Antoine, and Pierre Guérin. 2018. Financing Innovative Business Investment in Poland. OECD Economics Department Working Papers, No. 1480. Paris: OECD Publishing. [CrossRef]

Hall, Bronwyn H. 2010. The financing of innovative firms. Review of Economics and Institutions 1: 1-30. [CrossRef]

Hall, Bronwyn H., Francesca Lotti, and Jacque Mairesse. 2009. Innovation and productivity in SMEs: Empirical evidence for Italy. Small Business Economics 33: 13-33. [CrossRef]

Hottenrott, Hanna, and Bettina Peters. 2012. Innovative capability and financing constraints for innovation: More money, more innovation? Review of Economics and Statistics 94: 1126-42. [CrossRef]

Hueske, Anne-Karen, and Edeltraud Guenther. 2015. What hampers innovation? External stakeholders, the organization, groups and individuals: A systematic review of empirical barrier research. Management Review Quarterly 65: 113-48. [CrossRef]

Freel, Mark S. 2007. Are small innovators credit rationed? Small Business Economics 28: 23-35. [CrossRef]

Lecerf, Marjorie, and Nessrine Omrani. 2019. SME Internationalization: The Impact of Information Technology and Innovation. Journal of Knowledge Economy, 1-20. [CrossRef]

Lee, Neil, Hiba Sameen, and Marc Cowling. 2015. Access to finance for innovative SMEs since the financial crisis. Research Policy 44: 370-80. [CrossRef] 
Kerr, William R., and Ramanda Nanda. 2015. Financing innovation. Annual Review of Financial Economics 7: 445-62. [CrossRef]

Kersten, Renate, Job Harms, Kellie Liket, and Karen Maas. 2017. Small Firms, large Impact? A systematic review of the SME Finance Literature. World Development 97: 330-48. [CrossRef]

Kędzior, Marcin. 2012. Capital structure in EU selected countries-Micro and macro determinants. Argumenta Oeconomica 28: 69-117.

Kijkasiwat, Ploypailin, and Pongsutti Phuensane. 2020. Innovation and Firm Performance: The Moderating and Mediating Roles of Firm Size and Small and Medium Enterprise Finance. Journal of Risk and Financial Management 13: 97. [CrossRef]

Kovacevic, Tamara. 2019. EU Budget: Who Pays most in and Who Gets most back? BBC News. May 28. Available online: https://www.bbc.com/news/uk-politics-48256318 (accessed on 11 November 2019).

Kumar, Satish, and Purnima Rao. 2015. A conceptual framework for identifying financing preferences of SMEs. Small Enterprise Research 22: 99-112. [CrossRef]

Madeira, Maria José, João Carvalho, Jacinta Raquel Miguel Moreira, Filipe AP Duarte, and Flávio de São Pedro Filho. 2017. Barriers to innovation and the innovative performance of Portuguese firms. Journal of Business 9. [CrossRef]

Modigliani, Franco, and Merton H. Miller. 1958. The cost of capital, corporation finance and the theory of investment. The American Economic Review 48: 261-97.

Moritz, Alexandra, Block Joern H., and Heinz Andreas. 2016. Financing patterns of European SMEs-An empirical taxonomy. An International Journal of Entrepreneurial Finance 16: 115-48. [CrossRef]

Myers, Stewart C., and Nicholas S. Majluf. 1984. Corporate financing and investment decisions when firms have information that investors do not have. Journal of Financial Economics 13: 187-221. [CrossRef]

Neely, Lynn, and Howard Van Auken. 2012. An examination of small firm bootstrap financing and use of debt. Journal of Developmental Entrepreneurship 17: 1250002. [CrossRef]

OECD. 2013. Supporting Investment in Knowledge Capital, Growth and Innovation. Paris: OECD Publishing.

Oke, Adegoke, Gerard Burke, and Andrew Myers. 2007. Innovation types and performance in growing UK SMEs. International Journal of Operations Production Management 27: 735-53. [CrossRef]

Ortega-Argilés, Raquel, Macro Vivarelli, and Peter Voigt. 2009. R\&D in SMEs: A paradox? Small Business Economics 33: 3-11. [CrossRef]

Oslo, Manual. 2018. Oslo Manual 2018: Guidelines for Collecting, Reporting and Using Data on Innovation. Paris: OECD Publishing.

Ou, Charles, and Geogre W. Haynes. 2006. Acquisition of Additional Equity Capital by Small Firms-Findings from the National Survey of Small Business Finances. Small Business Economics 27: 157-68. [CrossRef]

Papadimitriou, Stratos, and Panos Mourdoukoutas. 2002. Bridging the start-up equity financing gap: Three policy models. European Business Review 14: 104-10. [CrossRef]

Pełka, Marcin. 2018. Analysis of innovations in the European Union via ensemble symbolic density clustering. Econometrics 22: 84-98. [CrossRef]

SAFE. 2018. Available online: https://ec.europa.eu/growth/access-to-finance/data-surveys (accessed on 30 September 2019).

Santarelli, Enrico, and Alessandro Sterlacchini. 1990. Innovation, formal vs. informal R\&D, and firm size: Some evidence from Italian manufacturing firms. Small Business Economics 2: 223-28. [CrossRef]

Sau, Lino. 2007. New Pecking Order Financing for Innovative Firms: An Overview. Working Paper Series. Torino: Universita di Torino, Available online: https://mpra.ub.uni-muenchen.de/3659/ (accessed on 25 March 2020).

Savlovschi, Ludovica Ioana, and Nicoleta Raluca Robu. 2011. The role of SMEs in modern economy. Economia, Seria Management 14: 277-81.

Schenk, Andreas. 2015. Crowdfunding in the context of traditional financing for innovative SMEs. In European Conference on Innovation and Entrepreneurship. Reading: Academic Conferences International Limited, pp. 636-43.

Schumpeter, Joseph A. 1942. Capitalism, Socialism and Democracy. New York: Harper.

Schumpeter, Joseph A. 1934. The Theory of Economic Development. Cambridge: Harvard Economic Studies.

Skuras, Dimitris, Kyriaki Tsegenidi, and Kostas Tsekouras. 2008. Product innovation and the decision to invest in fixed capital assets: Evidence from an SME survey in six European Union member states. Research Policy 37: 1778-89. [CrossRef] 
Tavassoli, Sam, and Charlie Karlsson. 2015. Persistence of various types of innovation analyzed and explained. Research Policy 44: 1887-901. [CrossRef]

Thurik, Roy, and Sander Wennekers. 2004. Entrepreneurship, small business and economic growth. Journal of Small Business and Enterprise Development 11: 140-49. [CrossRef]

Van Dijk, Bob, René Den Hertog, Bert Menkveld, and Roy Thurik. 1997. Some new evidence on the determinants of large-and small-firm innovation. Small Business Economics 9: 335-43. [CrossRef]

Vaona, Andrea, and Mario Pianta. 2008. Firm size and innovation in European manufacturing. Small Business Economics 30: 283-99. [CrossRef]

Varis, Miika, and Hannu Littunen. 2010. Types of innovation, sources of information and performance in entrepreneurial SMEs. European Journal of Innovation Management 13: 128-54. [CrossRef]

Vasilescu, Laura. 2014. Accessing Finance for Innovative EU SMEs Key Drivers and Challenges. Economic Review Journal of Economics and Business 12: 35-47.

Wadhwa, Anu, Corey Phelps, and Suresh Kotha. 2016. Corporate venture capital portfolios and firm innovation. Journal of Business Venturing 31: 95-112. [CrossRef]

Wu, Chuanrong, Xiaoming Yang, Veronika Lee, and Mark E. McMurtrey. 2019. Influence of Venture Capital and Knowledge Transfer on Innovation Performance in the Big Data Environment. Journal of Risk and Financial Management 12: 188. [CrossRef]

Whittam, Geoff Paul Stuart, and Janette Wyper. 2007. The pecking order hypothesis: Does it apply to start-up firms? Journal of Small Business and Enterprise Development 14: 8-21. [CrossRef]

Wolff, James A., and Timothy L. Pett. 2006. Small-firm performance: Modeling the role of product and process improvements. Journal of Small Business Management 44: 268-84. [CrossRef]

(C) 2020 by the authors. Licensee MDPI, Basel, Switzerland. This article is an open access article distributed under the terms and conditions of the Creative Commons Attribution (CC BY) license (http://creativecommons.org/licenses/by/4.0/). 